\title{
Knowledge of Undergraduate Medical Students of College of Medicine/ University of Baghdad Regarding Medical Ethics 2021
}

By

\section{Dr. Manwar Makki Razooqi ${ }^{* 1}$; Dr. Lamyaa Ali Hasan ${ }^{* 2}$; Ashwaq Ridha} Abdulsada ${ }^{* 3}$

${ }^{* 1}$ MBChB, /FM Practitionar / Baghdad teaching hospital/medical city/ ministry of Health and environment / Baghdad / Iraq; ${ }^{2}$ MBchB FICMS FM Consultant family medicine Almustanseryia PHC Training ${ }^{* 3}$ MBchB FICMS FM Family physician specialist, Almustanseryia PHC Training Center /Baghdad / Iraq

\begin{abstract}
Background: It is important to prepare the future doctors who are ethically competent to avoid medico legal issues in practice. Subjects and methods: A cross sectional study was conducted on 373 students from (15 January -15 April 2021) in Baghdad college of medicine where students in different stages from ( $1^{\text {st }}$ to $6^{\text {th }}$ Stage $)$ were asked to fulfil a pretested questionnaire which was distributed through internet and social media groups, it includes socio demographic variables of studied students in addition questions about knowledge of medical ethics, and data was introduced into spss v.23 statistical software. Results: shows that college curriculum was the source of information for $51.7 \%$ of the students, internet was the source in $38.1 \%$ and there was significant association between level of ethical knowledge and gender, in favor of female were $(59.4 \%)$ have good knowledge, while $(43.7 \%)$ for the male studied students. All the students have either good or fair knowledge in general and there was significant association between stage of students and level of ethical knowledge which was $(83.8 \%)$ good for the sixth stage students and significantly more than other stages (75.6\%), (73.2\%), (63.3\%), (48.7\%) and (23.8\%) for the fifth, fourth ,third, second and first year students respectively, $\mathrm{p}$ value $=0.001$. There was no significant association between gender and autonomy ,justice and dignity ,beneficence ,non-maleficence and veracity knowledge level $\mathrm{P}$ value $=(0.303),(0.064),(0.462),(0.114),(0.054)$ respectively. Conclusion: There is a good to fair knowledge in all stages regarding the medical ethics principles.
\end{abstract}

Keywords: Knowledge; Undergraduate Medical Students; College of Medicine; Medical Ethics. 


\section{Introduction}

The moral principles that should guide the members of the medical profession in their dealing with each-other, their patients and towards the state are dealt in medical ethics. These moral principles include respect for autonomy, non-maleficence, beneficence and justice ${ }^{(\mathbf{1})}$

Ethics reflects conduct, character, and the attitude of the doctor. There are several codes of conduct. The Main principles for medical professionals are discussed in Hippocratic oath. Hippocratic oath and Helsinki declaration put these ethical philosophies to get practiced in real medical life ${ }^{(2)}$ Ethics is always an essential part of healthcare. Advances in medical science have increase the ethical issues related to Health care. There has been growing public awareness toward the ethical conduct of medical practitioners, and complaints against physicians appear to be increasing Nowadays, modern technologies have blurred the line between medical ethics and quality of care. Medical practice throughout the world has become increasingly commercialized, and ethics has taken a backseat ${ }^{(3)}$. Ethical dilemmas usually seen in areas such as abortion, contraception, treatment of patients with a terminal illness, professional misconduct, maintaining a patient's confidentiality, the doctor's professional relationship with patient's relatives, religion, traditional medicine, and conflict of interest ${ }^{(4)}$ It is important to prepare the future doctors who are ethically competent to avoid medico legal issues in practice, there is crucial need to train the students about medical ethics, so that they are capable of solving any ethical issues, enable students to identify difficult situations and to deal with them in a rational and principled manner, to understand moral principles and analyses and define their own values and prevent themselves from ethical dilemmas during their own practice $^{(5)}$. Aim of the study: to assess knowledge among undergraduate students in different stages in Baghdad college of medicine 
regarding medical ethics.as well as determine association of students stages, gender and their ethical knowledge level.

Subjects and method :This cross-sectional study was conducted in college of medicine University of Baghdad during a period extended from (January April), 2020,The study included the students of Baghdad college of medicine, sample size was calculated according to sample size calculator which can be obtained from the web site location (6), from a population size of 2991 students, confidence interval $95 \%$ and margin of error 5, the estimated sample size was 350 , and we included 373 students in the study. We get the percentage of students in each stage from the whole population and the percentage of male and female in each stage and we distribute our sample according to these percentages, students in different stages from ( $1^{\text {st }}$ to final stage) both male and female were asked to fulfil a pretested questionnaire as a google form distributed through internet to measure medical students' knowledge regarding medical ethics.

The questionnaire was prepared as google form and distributed through social media groups for each stage to the medical students included in the study and students were asked to fill the questionnaire.

\section{Statistical analysis}

Data was introduced into spss v.23 statistical software. Descriptive statistics were presented using tables. Chi square test was used to find out significance of association between related categorical variables. P. Value $<0.05$ was considered as a discrimination point of significance.

\section{Results}

Table (1) shows that 101(27.1\%) were first year students, 78(20.9\%) second, 60(16.1\%) third, 56(15\%) fourth, 41(11\%) fifth, 37(9.9\%) sixth year medical students. Also $31.9 \%$ of the studied students were male, while $68.1 \%$ of the studied students were female. 
Table (1): Distribution of studied students according to essential characteristics

\begin{tabular}{|c||r|r|r|}
\hline \multicolumn{1}{|c|}{ Variable } & (No.=373) & \multicolumn{2}{|c|}{$\%$} \\
\hline \hline \multirow{4}{*}{ Stage } & First & 101 & 27.1 \\
\cline { 2 - 4 } & Second & 78 & 20.9 \\
\cline { 2 - 4 } & Third & 60 & 16.1 \\
\cline { 2 - 4 } & Fourth & 56 & 15.0 \\
\cline { 2 - 4 } & Fifth & 41 & 11.0 \\
\cline { 2 - 4 } & Sixth & 37 & 9.9 \\
\hline \hline \multirow{3}{*}{ Gender } & Male & 119 & 31.9 \\
\cline { 2 - 4 } & Female & 254 & 68.1 \\
\hline
\end{tabular}

Table (2) shows that there was no significant association between gender and autonomy knowledge level, $\mathrm{p}$ value $=0.303$, the autonomy level of knowledge of the sixth-year medical students was found to be (68.3\%) good which is significantly higher than that of other stages $(62.2 \%),(55 \%),(44.6 \%),(23.1)$, and $(9.9 \%)$ for the fifth, fourth, third, second- and first-year students respectively, $\mathrm{p}$ value $=0.001$.

Table (2): Association between stage, gender of studied students with their autonomy knowledge level

\begin{tabular}{|c|c|c|c|c|c|c|c|c|}
\hline & \multirow{2}{*}{ Variable } & \multicolumn{2}{|c|}{ Good } & \multicolumn{2}{|r|}{ Fair } & \multicolumn{2}{|c|}{ Poor } & \multirow{2}{*}{$\begin{array}{c}* \mathrm{P} \\
\text { value }\end{array}$} \\
\hline & & No. & $\%$ & No. & $\%$ & No. & $\%$ & \\
\hline \multirow{2}{*}{ Gender } & $\begin{array}{c}\text { Male } \\
(\text { No. }=119)\end{array}$ & 40 & 33.5 & 70 & 59 & 9 & 7.5 & \multirow{2}{*}{0.303} \\
\hline & $\begin{array}{c}\text { Female } \\
(\text { No. }=254)\end{array}$ & 97 & 38.2 & 145 & 57.1 & 12 & 4.7 & \\
\hline \multirow{2}{*}{ Stage } & $\begin{array}{c}\text { First } \\
(\text { No.=101) }\end{array}$ & 10 & 9.9 & 78 & 77.1 & 13 & 13 & \multirow{2}{*}{0.001} \\
\hline & $\begin{array}{c}\text { Second } \\
\text { (No.=78) }\end{array}$ & 18 & 23.1 & 54 & 67.9 & 6 & 9 & \\
\hline
\end{tabular}




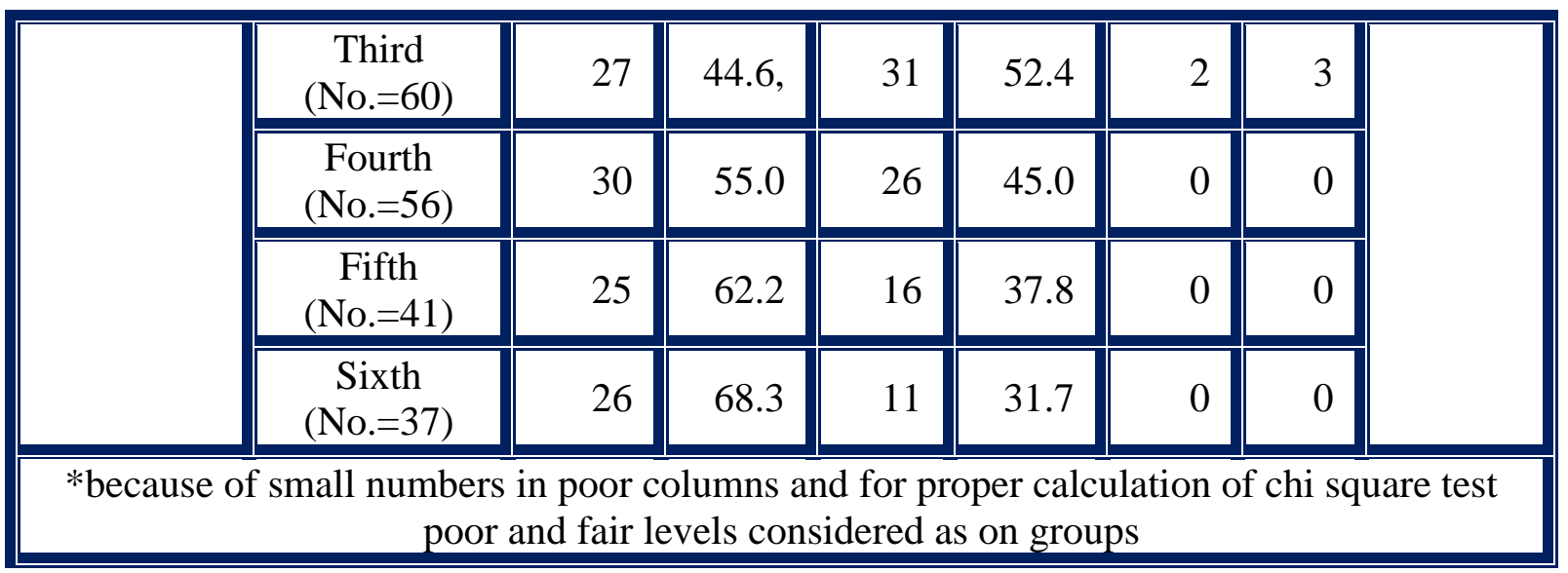

Table (3) shows that there was no significant difference between justice and dignity knowledge level and gender, $p$ value $=0.064$ or stage of students, $p$ value $=0.074$

Table (3): Association between justice and dignity knowledge level with gender and stage of studied students

\begin{tabular}{|c|c|c|c|c|c|c|}
\hline \multirow{2}{*}{\multicolumn{2}{|c|}{ Variable }} & \multicolumn{2}{|c|}{ Good } & \multicolumn{2}{|c|}{ Fair } & \multirow{2}{*}{$P$ value } \\
\hline & & No. & $\%$ & No. & $\%$ & \\
\hline \multirow{2}{*}{ Gender } & $\begin{array}{c}\text { Male } \\
(\text { No. }=119)\end{array}$ & 97 & 81.5 & 22 & 18.5 & \multirow{2}{*}{0.064} \\
\hline & $\begin{array}{c}\text { Female } \\
\text { (No. }=254)\end{array}$ & $\begin{array}{r}22 \\
5\end{array}$ & 88.6 & 29 & 11.4 & \\
\hline \multirow{6}{*}{ Stage } & $\begin{array}{c}\text { First } \\
(\mathrm{No}=101)\end{array}$ & 83 & 82.2 & 18 & 17.8 & \multirow{6}{*}{0.074} \\
\hline & $\begin{array}{c}\text { Second } \\
(\text { No. }=78)\end{array}$ & 66 & 84.6 & 12 & 15.4 & \\
\hline & $\begin{array}{c}\text { Third } \\
(\text { No. }=60) \\
\end{array}$ & 52 & 86.7 & 8 & 13.3 & \\
\hline & $\begin{array}{c}\text { Fourth } \\
(\mathrm{No} .=56) \\
\end{array}$ & 52 & 92.9 & 4 & 7.1 & \\
\hline & $\begin{array}{c}\text { Fifth } \\
(\text { No. }=41)\end{array}$ & 39 & 95.2 & 2 & 4.8 & \\
\hline & $\begin{array}{c}\text { Sixth } \\
(\text { No. }=37)\end{array}$ & 36 & 97.3 & 1 & 2.7 & \\
\hline
\end{tabular}

Table (4) shows that there was no significant association between gender and beneficence knowledge level, $\mathrm{p}$ value $=0.462$, the beneficence level of knowledge of the sixth year medical students was found to be $(83.8 \%)$ good 
which is significantly higher than that of other stages (78.05\%), (75\%), (73.3\%), $(61.5 \%)$ and (56.4\%) for the fifth, fourth, third, second and first year students respectively, $\mathrm{p}$ value $=0.003$.

Table (4): Association between beneficence Knowledge level with gender and stage of studied students

\begin{tabular}{|c|c|c|c|c|c|c|}
\hline \multirow{2}{*}{\multicolumn{2}{|c|}{ Variable }} & \multicolumn{2}{|c|}{ Good } & \multicolumn{2}{|c|}{ fair } & \multirow{2}{*}{$\begin{array}{c}P \\
\text { value }\end{array}$} \\
\hline & & No. & $\%$ & No. & $\%$ & \\
\hline \multirow{2}{*}{ Gender } & $\begin{array}{c}\text { Male } \\
(\text { No.=119) }\end{array}$ & 85 & 71.4 & 34 & 28.6 & \multirow{2}{*}{0.462} \\
\hline & $\begin{array}{c}\text { Female } \\
(\text { No. }=254)\end{array}$ & 171 & 67.3 & 83 & 32.7 & \\
\hline \multirow{6}{*}{ Stage } & First $(n=101)$ & 57 & 56.4 & 44 & 43.6 & \multirow{6}{*}{0.003} \\
\hline & Second (No.=78) & 48 & 61.5 & 30 & 38.5 & \\
\hline & Third (No.=60) & 44 & 73.3 & 16 & 26.7 & \\
\hline & Fourth $($ No. $=56)$ & 42 & 75 & 14 & 25 & \\
\hline & Fifth (No.=41) & 32 & 78.05 & 9 & 21.95 & \\
\hline & Sixth $($ No.=37) & 31 & 83.8 & 6 & 16.2 & \\
\hline
\end{tabular}

Table (5) shows that there was no significant association between gender and non-maleficence level of knowledge, $p$ value $=0.114$, the non-maleficence level of knowledge of the sixth-year students was found to be (43.3\%) good which is significantly higher than that of other stages (34.15\%), (26.7\%), (25\%), $(23 \%)$ and $(15.8 \%)$ for the fifth, fourth, third, second- and first-year students respectively, $\mathrm{p}$ value $=0.012$.

Table (5): Association between non maleficence knowledge level with gender and stage of studied students

\begin{tabular}{|c|c|c|c|c|c|c|c|c|}
\hline \multirow{2}{*}{\multicolumn{2}{|c|}{ Variable }} & \multicolumn{2}{|c|}{ Good } & \multicolumn{2}{|c|}{ fair } & \multicolumn{2}{|c|}{ poor } & \multirow{2}{*}{$\begin{array}{c}* \mathrm{P} \\
\text { value }\end{array}$} \\
\hline & & No. & $\%$ & No. & $\%$ & No. & $\%$ & \\
\hline \multirow{2}{*}{ Gender } & $\begin{array}{c}\text { Male } \\
(\text { No.=119) }\end{array}$ & 25 & $\begin{array}{r}21 . \\
0\end{array}$ & 84 & 70.6 & 10 & 8.4 & \multirow{2}{*}{0.114} \\
\hline & $\begin{array}{c}\text { Female } \\
(\text { No. }=254)\end{array}$ & 73 & $\begin{array}{r}28 . \\
7\end{array}$ & 169 & 66.5 & 12 & 4.7 & \\
\hline
\end{tabular}




\begin{tabular}{|c|c|c|c|c|c|c|c|c|}
\hline \multirow{6}{*}{ Stage } & $\begin{array}{c}\text { First } \\
(\text { No. }=101)\end{array}$ & 16 & $\begin{array}{r}15 . \\
8\end{array}$ & 75 & 74.3 & 10 & 9.9 & \multirow{6}{*}{0.012} \\
\hline & $\begin{array}{c}\text { Second } \\
(\text { No. }=78)\end{array}$ & 18 & 23 & 53 & 68.1 & 7 & 8.9 & \\
\hline & $\begin{array}{c}\text { Third } \\
(\text { No.=60) }\end{array}$ & 15 & 25 & 42 & 70 & 3 & 5 & \\
\hline & $\begin{array}{c}\text { Fourth } \\
(\text { No.=56) }\end{array}$ & 15 & $\begin{array}{r}26 . \\
7\end{array}$ & 39 & 71.8 & 2 & 3.5 & \\
\hline & $\begin{array}{c}\text { Fifth } \\
(\text { No.=41) }\end{array}$ & 18 & $\begin{array}{r}34 . \\
15\end{array}$ & 25 & $\begin{array}{r}65.8 \\
5\end{array}$ & 0 & 0 & \\
\hline & $\begin{array}{l}\text { Sixth } \\
(\mathrm{n}=37)\end{array}$ & 16 & $\begin{array}{r}43 . \\
3\end{array}$ & 21 & 57.7 & 0 & 0 & \\
\hline
\end{tabular}

Table 6 shows that there was no significant association between gender and Veracity knowledge level, $\mathrm{p}$ value $=0.054$, the Veracity level of knowledge of the sixth-year medical students was found to be (97.3\%) good which is significantly higher than that of other stages (95.2\%), (90.9\%), (83.3\%), $(82.6 \%)$ and $(80.2 \%)$ for the fifth, fourth, third, second- and first-year students respectively, $\mathrm{p}$ value $=0.042$.

Table (6): Association between veracity knowledge level with gender and stage of studied students

\begin{tabular}{|c|c|c|c|c|c|c|}
\hline \multirow{2}{*}{\multicolumn{2}{|c|}{ Variable }} & \multicolumn{2}{|c|}{ Good } & \multicolumn{2}{|c|}{ Fair } & \multirow{2}{*}{$\begin{array}{c}\mathrm{P} \\
\text { value }\end{array}$} \\
\hline & & No. & $\%$ & No. & $\%$ & \\
\hline \multirow{2}{*}{ Gender } & $\begin{array}{c}\text { Male } \\
(\text { No.=119) }\end{array}$ & 95 & 79.8 & 24 & 20.2 & \multirow{2}{*}{0.054} \\
\hline & $\begin{array}{c}\text { Female } \\
(\text { No.=254) }\end{array}$ & 220 & 86.6 & 34 & 13.4 & \\
\hline \multirow{3}{*}{ Stage } & $\begin{array}{c}\text { First } \\
(\text { No. }=101)\end{array}$ & 81 & 80.2 & 20 & 19.8 & \multirow{3}{*}{0.042} \\
\hline & $\begin{array}{c}\text { Second } \\
\text { (No.=78) }\end{array}$ & 64 & 82.6 & 14 & 17.4 & \\
\hline & Third (No. $=60)$ & 50 & 83.3 & 10 & 16.7 & \\
\hline
\end{tabular}




\begin{tabular}{|c||c||r|r|r|r||r||}
\hline \multirow{2}{*}{$\begin{array}{c}\text { Fourth } \\
\text { (No.=56) }\end{array}$} & 51 & 90.9 & 5 & 9.1 \\
\cline { 2 - 6 } & Fifth (No.=41) & 39 & 95.2 & 2 & 4.8 \\
\cline { 2 - 6 } & Sixth (No.=37) & 36 & 97.3 & 1 & 2.7 \\
\hline
\end{tabular}

Table (7) shows that there was significant association between level of ethical knowledge and gender, in favor of female (59.4\%) good, while (43.7\%) for the male studied students $\mathrm{p}$ value $=0.004$

And there was significant association between stage of students and level of ethical knowledge which was $(83.8 \%)$ good for the sixth stage students and significantly more than other stages $(75.6 \%),(73.2 \%),(63.3 \%),(48.7 \%)$ and $(23.8 \%)$ for the fifth, fourth, third, second- and first-year students respectively, $\mathrm{p}$ value $=0.001$.

Table (7): Association between studied students gender and their stage with the level of ethical knowledge

\begin{tabular}{|c|c|c|c|c|c|c|}
\hline \multirow{2}{*}{\multicolumn{2}{|c|}{ Variable }} & \multicolumn{2}{|c|}{ Good } & \multicolumn{2}{|c|}{ Fair } & \multirow{2}{*}{$P$ value } \\
\hline & & No. & $\%$ & No. & $\%$ & \\
\hline \multirow{2}{*}{ Gender } & $\begin{array}{c}\text { Male } \\
(\text { No. }=119)\end{array}$ & 52 & 43.7 & 67 & 56.3 & \multirow{2}{*}{0.004} \\
\hline & $\begin{array}{c}\text { Female } \\
(\text { No. }=254)\end{array}$ & 151 & 59.4 & 103 & 40.6 & \\
\hline \multirow{6}{*}{ Stage } & $\begin{array}{c}\text { First } \\
(\text { No. }=101)\end{array}$ & 24 & 23.8 & 77 & 76.2 & \multirow{6}{*}{0.001} \\
\hline & $\begin{array}{c}\text { Second } \\
(\text { No. }=78)\end{array}$ & 38 & 48.7 & 40 & 51.3 & \\
\hline & Third $($ No. $=60)$ & 38 & 63.3 & 22 & 36.7 & \\
\hline & Fourth $($ No. $=56)$ & 41 & 73.2 & 15 & 26.8 & \\
\hline & Fifth (No.=41) & 31 & 75.6 & 10 & 24.4 & \\
\hline & Sixth (No.=37) & 31 & 83.8 & $\overline{6}$ & 16.2 & \\
\hline
\end{tabular}

Table (8) shows that college curriculum was the source of information for $51.7 \%$ of the students, internet was the source in $38.1 \%$, Television was the source in $3.5 \%$, peer group was the source in $1.9 \%$, and others was $4.8 \%$. 
Table (8): Distribution of studied students according to source of information

\begin{tabular}{|c|r|r|}
\hline & No.=373 & \multicolumn{1}{|c|}{$\%$} \\
\hline \hline college curriculum & 193 & 51.7 \\
\hline \hline Internet & 142 & 38.1 \\
\hline \hline peer group & 7 & 1.9 \\
\hline \hline Television & 13 & 3.5 \\
\hline Others & 18 & 4.8 \\
\hline
\end{tabular}

\section{Discussion}

Future doctors must be provided scientific knowledge within the context of the ethical basis of their relationship with the patients and they must understand how the human values are rooted in clinical decision making. This would help to have better treatment outcome and enhanced patient satisfaction. It has been found that teaching medical ethics has a deep impact on medical professionals' attitudes and decision making. ${ }^{(7)}$

Regarding source of information, the main source of medical ethics was the college curriculum ,followed by the internet, same as a study done by Farhan Ahmed Majeed ${ }^{(\mathbf{8})}$ which showed that lectures and seminars was the source of information in $90 \%$ of the students while in a study done by Suja Purushothaman in India ${ }^{(9)}$ the main source of the information was Newspaper, internet, television 50\%, while peer groups and discussion among doctors was the source in $30 \%$, and in a study done by Ramesh P Aacharya in Bangladesh (10) the most common source was lectures/seminars (35.7\%) followed by experience at work $(24.5 \%)$, training $(21.4 \%)$ and own reading (17.3\%), this differences may be due to different curriculums between the universities and difference in concentration on the medical ethics by each university.

In this study there was a significant difference in the knowledge between male and female in favor of female, same as in a study done by Tabinda A, 
Aiesha in Pakistan ${ }^{(\mathbf{1 1})}$, While in the study of Farhan Ahmed Majeed ${ }^{(\mathbf{8})}$, There was no significant differences in mean scores of ethics scale among males and females, this difference may be due to the female students in our study have more commitment to the lectures and seminars and study more than males students and may also due to higher number of female students in sample included in this study according to the real total number .

Regarding the awareness of importance of medical ethics, most of the responses was strongly agree with it, which is comparable to the results of a study conducted in Egypt ${ }^{(\mathbf{1 2})}$ and India ${ }^{(\mathbf{1 3})}$ where $99.2 \%$ and $99 \%$ respectively said that it was necessary to inculcate Code of Ethics in undergraduate curriculum and in Ramesh P Aacharya ${ }^{(10)}$ the range of medical ethics importance questions was between $87 \%$ and 91\%,And in Farhan Ahmed Majeed study ${ }^{(8)} 59.1 \%$ of undergraduates said that teaching medical ethics to undergraduates was necessary.

Regarding autonomy questions, there was fair knowledge in the $1^{\text {st }}, 2^{\text {nd }}$ and $3^{\text {rd }}$ stages students, while there was a good knowledge in the $4^{\text {th }}, 5^{\text {th }}$ and $6^{\text {th }}$ Stage, while in Isawarya study ${ }^{(14)}$ the range of the knowledge in autonomy related questions was ranging from $19 \%$ to $87 \%$. While in a study done in Kalkata by Rekha Dutt ${ }^{(\mathbf{1 5}),}$ the knowledge of students was between $7 \%$ and 78 $\%$, where number increase in awareness with increase in years. and in a study of Ramesh P Aacharya ${ }^{(10)}$ the range of knowledge was between $78 \%$ an $82 \%$, meanwhile another study done by sunil Kumar ${ }^{(16)}$ in Pakistan the range of knowledge was around $69 \%$ (the study done on the final three stages in the college).and in a study done by Biswajit Chatterjee ${ }^{(\mathbf{1 7})}$ in west Bengal the range was between 54\% and 82\%.Regarding justice and dignity, the good knowledge was prominent in all stages which was increasing proportionally with increasing the Stage, nearly similar results found in Sunil kumar ${ }^{(16)}$ was around $97 \%$, whilein Ramesh P Aacharya ${ }^{(\mathbf{1 0})}$ the knowledge of justice related questions was 43\%. And in Biswajit Chatterjee study ${ }^{(17)}$ the knowledge was between $44 \%$ and 
$77 \%$ and in Isawarya study ${ }^{(14)}$ the knowledge was around $35 \%$.Regarding beneficence questions, the good knowledge was prominent in all stages which was increasing proportionally with increasing the stage, While in Isawarya study ${ }^{(14)}$ the knowledge was around $30 \%$, and in Rekha Dutt ${ }^{(\mathbf{1 5})}$ study was between $30 \%$ and $79 \%$. and in Biswajit Chatterjee ${ }^{(17)}$ study the range was between $30 \%$ and $46 \%$.

In general, no other study categorized the responses of the students according to the main ethics principles, so we compare with the range of responses to the questions related to each principle, all the students have either Good or Fair knowledge about medical ethics, good in all stages for justice and dignity, beneficence and veracity, while good in $4^{\text {th }}, 5^{\text {th }}, 6^{\text {th }}$ stages for autonomy and fair for non maleficence, we don't have students with poor knowledge for the whole questionnaire, while in a study done by Biswajit Chatterjee ${ }^{(17}$ ') in West Bengal nearly $4 \%$ of the students had poor knowledge, 37\% fair knowledge, $51 \%$ good knowledge and $8 \%$ very good knowledge, while in Sunil Kumar ${ }^{(16)}$ there was an overall deficiency in knowledge regarding main principles, $18.4 \%$ of students could give the correct response to all principles, same for Isawarya ${ }^{(14)}$ were lack of knowledge of final years. Again, this difference may be related to difference in curriculum, the good curriculum that respects the medical ethics and gives it importance by lectures, seminars and workshops from the first to the fourth year and in clinical sessions later on.

There was significant association between level of autonomy, beneficence, veracity and non maleficence with stage of students, also there was significant association between stage of students and level of ethical knowledge, which may be due to accumulative effect of lectures, seminars and clinical rounds experience.

Conclusions: There was a good to fair knowledge and awareness in general for the undergraduate medical students of Baghdad college of medicine regarding medical ethics, so female knowledge was significantly better than 
male, as well as there was a less knowledge regarding non maleficence and autonomy principles, and good knowledge regarding veracity, justice and dignity.

\section{References}

1) Beauchamp TL and Childress JF. Principles of Biomedical ethics. 7th Ed. Oxford: Oxford University Press. 2013.available at https://www.researchgate.net/publication/12869379_Principles_of_biome dical_ethics

2) Waleed AT AL-Ani, Ahmed K.Al-Delaimy, Assessment of the understanding of medical ethics subject among Anbar medical group students. medico legal update 2020;20(1) https:doi.org \10.37506\mlu.v20i1.462

3) Chopra M, Bharadwaj A, Mitha P, Sign A, Siddiqui A, Rajesh PR. Currnt status of Knowledge, Attitude ad Practices towards Healthcare Ethics among Doctors and Nurses from North Indaia-A Multicenter Study. JKIMSU. 2013;2:102-7.

4) Janakiram C, Gardens SJ. Knowledge, Attitudes And Practices Related To Healthcare Ethics Among Medical And Dental Postgraduate Students In South India. Indian J Med Ethics. 2014; 11(2): 99-104. doi:10.20529/IJME.2014.025.

5) Ainun Afroza, Module for Teaching Medical Ethics to Undergraduates, World Health Organization 2009 p.11-14,available at https://apps.who.int/iris/bitstream/handle/10665/205534/B4401.pdf?sequ ence $=1$

6) Creative research system, sample size calculator, available at : https://www.surveysystem.com/sscalc.htm

7) Fong Ha J, Longnecker N. Doctor-Patient Communication: A Review. Ochsner J. 2010; 10 (1): 38-43.

8) Farhan A. M, Muhammad W.S, Abdul Rehman A. Awareness of medical Ethics among undergraduate medical studwnts In A Private Medical School: A Cross Sectional Survey. Pak Armed Forces Med J 2020; 70 (Suppl-1): S37-44

9) Suja Purushothaman , Deepalaxmi salmani , Somashekhar S. et al, indian Journal of Clinical Anatomy and Physiology, January-March, 2017;4(1):97-99 
10) Aacharya RP, Shakya YL. Original article knowledge, attitude and practice of medical ethics among medical intern students in a Medical College in Kathmandu. Bangladesh J Bioeth 2015; 6(3): 1-9.

11) Tabinda A, Aiesha I, Faisal S, Fahad S. Knowledge and perception about bioethics: A comparative study of private and government medical college students of Karachi Pakistan. J Family Med Prim Care. 2021 Mar;10(3):1161-6.

12) Mohamed M, Ghanem M, Kassem A. Knowledge, perceptions and practices towards medical ethics among physician residents of University of Alexandria Hospitals, Egypt. East Mediterr Health J 2012; 18(9): 93545.

13) Brogen AS, Rajkumari B, Laishram J, Joy A. Knowledge and attitudes of doctors on medical ethics in a teaching hospital, Manipur. Indian J Med Ethics 2015; 6(4): 194-97.

14) Iswarya S., Bhuvaneshwari S. Knowledge and attitude related to medical ethics among medical students.Jcmph 2018;5(6) DOI: http://dx.doi.org/10.18203/2394-6040.ijcmph20182065. Vol 5, No 6 (2018)

15) Rekha Dutt. Awareness of Medical Ethics among Undergraduate Students of Medical College in South Kolkata Indian Journal of Public Health Research \& Development, December 2019, Vol. 10, No. 12:725.

16) Sunil K.Iatana ,Htoo K.S,Khrne L.p.et al.A Survey on Knowledge and Attitudes towards Medical Ethics among Undergraduate Medical Students. Education , 2018; 8(3): 48-53, DOI: 10.5923/j.edu.20180803.03

17) Chatterjee B, Sarkar J. Awareness of medical ethics among

18) undergraduates in a West Bengal medical college. Indian J Med Ethics 2017; (2):93-100. 